\title{
Factors Of Market Performance Of Apple Ipod: A Preliminary Desk-Based Study
}

Eric Shiu, (Email: e.c.shiu@bham.ac.uk), University of Birmingham, United Kingdom

\begin{abstract}
The Apple iPod is a hugely successful new product. This study conducts a secondary research in order to trace the technical and market development of the product, and then to suggest contributory factors of its remarkable market performance. These suggested contributory factors include opportunity identification, product design, product platform, external and internal coordination, speed to market, and advertisement and publicity. Future research can incorporate all these factors in a hypothetical causal model in order to test the statistical significance of these factors and the relative importance between them.
\end{abstract}

\section{INTRODUCTION}

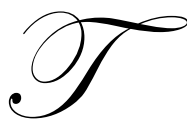

he Apple iPod is a small, portable digital music player. Its original version has a $5 \mathrm{~GB}$ hard drive, thus enabling it to store up to 100 hours of MP3 music files. The lithisum-polymer battery powers the iPod for ten hours between charges. The small device features a high-resolution liquid-crystal display and a thumb-wheel to scroll through the menus. There is a headphone-jack and a socket to connect the iPod to a computer using a firewire cable, which allows high-speed transfers of digital files. It also contains memory chips and various other circuitries including a microprocessor. The iPod comes with Apple's iTunes digital-jukebox software, which gives users the ability to organise their music into play lists (Schlender 2001).

New products usually face a high rate of failure somewhere in the order of 25 to 45 percent (Cooper 2001). Despite this norm, the market launch of Apple iPod has proved to be hugely successful. After the dot com crash, Apple's share price tumbled and didn't recover until 2004 when it dramatically tripled towards US\$80 a share. During the first financial quarter of 2005, Apple registered its highest revenue and profit in its 28 years of history. This has been propelled by the sale of 4.6 billion iPods, occupying $74 \%$ market share of the digital market (Mac Publishing 2005). The iPod is now bigger than the whole of Apple in 1995. Table 1 illustrates further the market performance of iPod based on measures including sales volume, market share and profitability, all of which have been claimed as effective measures of performance (Crawford 2003).

\section{RESEARCH OBJECTIVE AND APPROACH}

An increasing amount of research, field-based or desk-based, has been conducted on the factors of success of a new product (e.g. Ayers, Dahlstrom and Skinner 1997; Moorman and Miner 1997; Ittner and Larcker 1997; Song and Parry 1997; Edgett, Shipley and Forbes 1991). Many of these studies endeavoured to come up with factors that can account for new product success. They have contributed significantly to our clearer understanding of the causal relationship between these factors and new product performance in general. 
Table 1 - Sale Volume, Market Share And Profitability Of Apple Ipod

\begin{tabular}{|l|l|}
\hline December 2003 & Apple has sold 1.3 million iPods so far. \\
\hline January 2004 & Apple has 31\% share in the digital music player market. \\
\hline January 2004 & Apple boasts a net profit for $1^{\text {st }}$ quarter of \$63 million. \\
\hline February 2004 & iTunes is the most popular music-download store. \\
\hline April 2004 & Apple reports a net profit of \$46 million in the $2^{\text {nd }}$ quarter of 2004. \\
\hline April 2004 & Apple has sold more than 70 million songs via iTunes in its first year (Mintel 2005). \\
\hline April 2004 & iTunes controls 70\% of the music-download business (Quittner 2004). \\
\hline July 2004 & Over 3 million people now own iPods (Stone et al. 2004). \\
\hline October 2004 & $\begin{array}{l}\text { Apple announced a 44\% year on year increase in profit to \$106 million. This is due to a 344\% } \\
\text { increase in sales from iPods and a 600\% increase in sales from iTunes (Bulik 2004). }\end{array}$ \\
\hline October 2004 & Apple has 66\% share of the market for digital music players (Burrows 2004). \\
\hline December 2004 & $\begin{array}{l}\text { 65\% of all MP3 players are iPods and 92\% of all hard drive-based music players are iPods } \\
\text { (Vence 2004). }\end{array}$ \\
\hline
\end{tabular}

However, it is always likely that the factors that are validated in a study may be quite country-specific or product-specific. For example, cross-functional integration, which measures 'internal environment', is influential in new product performance for both the US and Japan, but the magnitudes of the influence are different (Ayers, Dahlstrom and Skinner 1997; Song and Parry 1997). 'Competitive environment' exerts a significant impact on new product performance within the electronic products industry (Zirger and Maidique 1990) and the industrial products industry (Cooper 1979). Yet Cooper and Kleinschmidt (1987) found that the same category of determinants is significantly and negatively correlated with only one of ten measures of new product success for a wider scope of industries. In 1993, the same authors focused on the chemical industry and concluded that 'competitive factors did not discriminate much between successful new products and unsuccessful ones'. Take another example, preannouncement can be beneficial in one new product launch setting, but can have disastrous consequence in another. Considering all these potential complications, this study concentrates on only one product - Apple iPod, whose remarkable market performance is not country specific.

The market performance of Apple iPod is indisputable. It is proclaimed as one of the top ten most successful product launches (Advertising Age 2003). Smith (2004) also maintains that the iPod is 'one of the most successful products launched in the last decade'. It would be beneficial for businesses, particularly technology businesses, to understand what could be contributing to the huge success of Apple iPod, which becomes the research objective of this study.

To meet this research objective, the study will borrow established concepts in new product development and hi-tech product marketing, such as product design, product platform and speed to market, in order to offer explanations of the market performance of Apple iPod. This is accompanied by secondary research of the technical and market development of the product. Undeniably this study is a desk-based study, and therefore any contributory factors suggested are still to be validated. The following section is an account of these factors.

\section{SUGGESTED FACTORS OF PERFORMANCE}

Through a desk research on factors of new product success in general and Apple iPod in particular, six factors of performance of the product have been proposed. These six factors could be crucial, but not exhaustible.

\section{Opportunity Identification}

Opportunity identification is the first stage of product innovation process, and is 'strategic in nature' (Crawford 2003) because everything that follows along the process is all about to effectively and efficiently take up the opportunity concerned. However, it is often difficult to identify opportunities and choose the best of all these opportunity. Crawford (2003) once noted that opportunity identification is the fuzziest stage of the product innovation process. 
Apple had effectively identified an opportunity within the digital music market. They had noticed that 'digital music players weren't selling' because the products currently on the market were insufficient (Stone et al. 2004). Smith (2004) notes that 'Apple saw that the digital music players were lousy'.

\section{Product Design}

It appears that the iPod was designed with a number of desired attributes in mind. The product uses 1.8" Toshiba hard drive technology, rather than the conventional flash memory facility, to store music. Until then, the Toshiba technology had not been used on other similar products. This suggests that Apple wants to benefit from design differentiation by enabling users to store their entire music collection, as opposed to a selection of songs, onto a device. By storing music songs onto its memory chips, the power-hogging hard drive developed by Sony is allowed to shutdown during playback, which results in a battery life of ten hours compared to two hours of its competitors (Brent 2001).

In addition, Apple iPod was designed to meet customers' functional needs in that an ingenious two-inchdiameter thumb-wheel is incorporated on the faceplate for scrolling through hierarchical menus on the six-line display. Furthermore, firewire connectivity has been utilised to allow high-speed transfer of digital files, which is in direct contrast to its competitors who all used the slower USB connections. The functionality of the product is further enhanced with the use of the iTunes software, which allows easy transfer synchronisation of new files from the computer onto the iPod, and also allows playlists to be effortlessly created and categorised.

The design is not only functionally attracting the customers, but also aesthetically pleasing to them. The product is represented by the sleek lines with the less conventional white colour, and provides a sense of userfriendliness. These are all in line with and therefore further enhance the established corporate image of Apple (Crawford 2003).

The ease of manufacture is also evident, as the iPod's casing is clipped together instead of the use of more time-consuming screw fixings (Brent 2001).

The high quality design of iPod could be summed up by Donaldson (2002), who commends that 'Apple has always been ahead of the curve when it comes to innovative design ... with the new iPod MP3 player, the company sets another benchmark'.

\section{Product Platform}

The original iPod was designed in a way that it can be treated as a product platform, which 'can be shared by one or more product families' (Crawford 2003), and can incorporate new advancements and add-ons to be developed at a later stage. Schlender (2001) states that the team behind the iPod 'knew they were designing what was in effect a computer platform that could be improved with software upgrades and adapted to other uses'. The product platform strategy can help to further increase sales of the product by introducing continuously improved versions of the product. This can be seen with the advent of the second, third, and fourth generation iPods' all offering advanced features over their predecessors, as well as the iPod Mini, iPod Photo and most recently the iPod Shuffle (Burrows 2004). Table 2 outlines the launch of Apple iPod and its next generation products. 
Table 2 - Launch Of Apple iPod

\begin{tabular}{|l|l|}
\hline February 2001 & $\begin{array}{l}\text { Having recognised an opportunity in the digital music player market, Steve Jobs (CEO of } \\
\text { Apple) put together a team to come up with a 'groundbreaking' digital music player. }\end{array}$ \\
\hline October 2001 & Launch of the 5GB Apple iPod, priced at \$399 (Levy and Stone 2004). \\
\hline June 2003 & $\begin{array}{l}\text { Apple launches a new improved iPod, with 10GB (\$299), 15GB (\$399) and 30GB (\$499) } \\
\text { hard disks. The device is slimmer than the original model, includes a docking station and the } \\
\text { user can now store up to 500 hours of MP3s. New features include a song-rating facility } \\
\text { (Dreier 2003). }\end{array}$ \\
\hline October 2003 & $\begin{array}{l}\text { Apple launches iTunes music store (in USA); consumers can purchase songs to play on their } \\
\text { iPods. }\end{array}$ \\
\hline January 2004 & Apple makes a pre-announcement for the launch of its new Mini iPod. \\
\hline February 2004 & Apple launches the Mini iPod. \\
\hline March 2004 & $\begin{array}{l}\text { The global launch of the mini iPod is delayed due to stronger demand than expected. It had } \\
\text { been planned to launch worldwide in April. }\end{array}$ \\
\hline June 2004 & Apple launches iTunes in Britain. \\
\hline July 2004 & Mini iPod is launched internationally at a price of \$249. \\
\hline July 2004 & $\begin{array}{l}\text { Apple introduces a new iPod available in a 20GB model (\$299) and 40GB (\$399). It features } \\
\text { a click wheel, 12 hours of battery life and a new 'shuffle' feature. It is also slightly thinner } \\
\text { than its predecessor. }\end{array}$ \\
\hline October 2004 & $\begin{array}{l}\text { Apunes is launched in 9 more European countries. } \\
\text { The 40GB model costs \$499 and the 60GB model costs \$599. }\end{array}$ \\
\hline October 2004 & Apple launches the iPod Shuffle, a lightweight, cheaper version of the standard iPod. \\
\hline January 2005 & $\begin{array}{l}\text { Apple cuts the price of iPods - the iPod Mini costs \$199 (previously \$249), the 60GB iPod } \\
\text { photo is \$499 and the 40GB version is \$349 (Mintel 2005). }\end{array}$ \\
\hline March 2005 & \\
\hline
\end{tabular}

\section{External And Internal Coordination}

To achieve the best possible functions of the product, Apple strategically coordinated with companies with core competencies in respective areas all of which contribute to the functional performance of the product. Table 3 outlines the key partners of Apple for the development of its iPod product.

Table 3 - Apple's Key Partners And Their Respective Expertise Areas

\begin{tabular}{|c|c|}
\hline Company & Component \\
\hline Sony & Battery \\
\hline Wolfson & Codec/DAC \\
\hline Toshiba & Disk drive \\
\hline Texas Instrument & Firewire \\
\hline Linear Technology & Power management \\
\hline
\end{tabular}

Apple used dual approaches in internally coordinating its specialists for the development of the iPod product. A functional approach was initially utilized in order to project the secrecy of the iPod's development, as many employees were enlisted without knowing what the final aim of their work was. A total of approximately 50 specialists were working on the iPod at any one time, consisting of 35 designers and a handful of software and hardware engineers, including several from outside the company. Many Apple engineers drifted in and out of the project as their expertise was needed. 
This then transformed into a venture based approach, with employees being pulled from their original departments to work fulltime on the iPod and to establish new ideas to solve product related problems.

\section{Speed To Market}

The advantages for a company to bring its newly developed products to market as fast as possible can be crucial. Cooper (2001) advocates that 'speed is the pivotal competitive weapon: the ability to accelerate product innovation - to get new products to market ahead of the competition and within the window of opportunity - is more than ever central to success', and speed to market is particularly necessary in an environment where 'markets and technologies are changing more quickly than ever'.

Apple achieved a very rapid entry into the digital music player market. They progressed from opportunity identification in February 2001 to market launch in October 2001 in just 8 months. This is faster than any other major product in the company's history (Brent 2001). They managed to do this before the competitors realised the same opportunity, which eventually contributed to their attaining clear market leadership.

Apple not only speeded up the launch time in order to get ahead of potential competitors, but also timed the launch time nicely in order to obtain the maximum possible initial sales. The first version of Apple iPod was launch in October, right just before the Christmas shopping season, when demand for the product was expected to be the greatest than otherwise (Schlender 2001). This launch timing strategy dovetails Hisrich and Peters' (1991) suggestion of the importance of the timing of new product launch.

\section{Advertisement And Publicity}

Advertising is important in new product launch as it can help to increase the awareness of the product amongst the public, which is 'the necessary first step towards adoption' (Crawford 2003). Apple has launched a successful advertising campaign for its iPod product (Creativity 2004). The advertisement, on the television, depicts silhouetted bodies dancing along to the music played by their iPods. The bright white iPods are in contrast with the bold colours in the background, which results in a strikingly visual effect. The advertisement emphasises on 'the enjoyment of music on the go' (Vence 2004).

Apple has also benefited from free publicity for the iPod. Hisrich and Peters (1991) argue that 'one of the most effective means of facilitating the introduction of a new product is to obtain free advertising'. Apple achieved free publicity from articles in newspapers and magazines whereby the features and benefits of the iPod were reviewed (Mintel 2005). It further gained free publicity when David Beckham was seen in the newspaper using his iPod, which helped to boost demand (Mintel 2005). Will Smith also provided free publicity for the iPod by talking on a chat show about his infatuation with the 'gadget of the century' (Stone et al. 2004).

\section{CONCLUSIONS}

The iPod has clearly been a highly successful new product, with an increasingly high level of sales since its launch in October 2001, and a market share of over $60 \%$. This success can be attributed to a number of contributory factors discussed above and summarised below.

Apple has identified an opportunity in a growing market and has exploited it effectively by coming up with a concept that is valued by consumers. The iPod is an innovative idea which was brought rapidly to the market, and the competition could not match its outstanding design and functionality. Cooper (2001) argues that a successful new product is 'a unique, superior and differentiated product with good value for money for the customer'. The iPod fulfils each one of these criteria. The launch of the iPod has been supported by an effective advertising campaign, and has been further strengthened by a number of publicity events, which have established the product as a 'cultural icon' (Bulik 2004). Apple constantly makes improvements to the iPod in order to sustain its market leadership status. 
The success of the iPod is likely to continue into the future. Using the iPod as a product platform, Apple is able to have further product innovations. Possibilities include a wireless iPod which uses Bluetooth to connect to a computer without a docking station, a vPod which plays videos, and an iPhone which allows users to play MP3 on their mobile phone (Sloan 2005).

\section{REFERENCES}

1. $\quad$ Advertising Age (2003) Ten most successful product launches, Advertising Age, Vol. 74, Issue 51, p. 26.

2. Ayers, Doug, Robert Dahlstrom, and Steven J. Skinner (1997) An exploratory investigation of organisational antecedents to new product success, Journal of Marketing Research, 34 (February), p. 107-116.

3. Brent, S. (2001) Apple's $21^{\text {st }}$ century walkman, Fortune (Europe), November, 144 (9), p. 113.

4. Bulik, B.S. (2004) The iPod economy, Advertising Age, Vol.75, Issue 42, p. 1-2.

5. $\quad$ Burrows, Peter (2004) A rising iPod lifts all boats, Business Week Online.

6. Cooper, Robert G. (1979) The dimensions of industrial new product success and failure, Journal of Marketing, 43 (summer), p. 93-103.

7. Cooper, Robert G. (2001) Winning at New Products, Perseus Books.

8. Cooper, Robert G. and Elko J. Kleinschmidt (1987) New products: what separates winners and losers? Journal of Product Innovation Management, 4 (3), p. 169-184.

9. Crawford, M. and Di Benedetto, A. (2003) New Products Management, McGraw-Hill.

10. Creativity (2004) Campaign: Apple iPod, Vol. 12, Issue 1, p. 2.

11. Donaldson, S.A. (2002) New products, Black Enterprise, Vol. 32, Issue 8, p.56.

12. Edgett, Scott, David Shipley, and Giles Forbes (1991) Japanese and British companies compared: contributing factors to success, Journal of Product Innovation Management, 9 (1), p. 3-10.

13. Hisrich, R.D. and M.P. Peters (1991) Marketing Decisions for New and Mature Products, Macmillan Publishing Company.

14. Ittner, Christopher D. and David F. Larcker (1997) Product development cycle time and organisational performance, Journal of Marketing Research, 34 (February), p. 13-23.

15. Mac Publishing (2005) http://www.macworld.com accessed on 25 April 2005.

16. Mintel (2005), http://mintel.com accessed on 25 April 2005.

17. Moorman, Christine and Anne S. Miner (1997) The impact of organisational memory on new product performance and creativity, Journal of Marketing Research, 34 (February), p. 91-106.

18. Schlender, Brent (2001) Apple $21^{\text {st }}$ century walkman, Fortune (Europe), Vol. 144, Issue 9, p. 113-117.

19. Sloan, Paul (2005) What's next for Apple? Business 2.0, Vol. 6, Issue 3, p. 68-75.

20. Smith, Steve (2004) iPod's Lessons, This Week in Consumer Electronics, Vol. 19, Issue 15, p. 12.

21. Song, X. Michael and Mark E. Parry (1997) The determinants of Japanese new product successes, Journal of Marketing Research, 34 (February), p. 64-76.

22. Stone, et al. (2004) iPod Nation, Newsweek, Vol. 144, Issue 4, p. 42-50.

23. Vence, D.L. (2004) Ad campaign, simplicity drives sales of Apple iPod, Marketing News, Vol. 38, Issue 20, p. 16.

24. Zirger, Billie Jo and Modesto A. Maidique (1990) A model of new product development: an empirical test, Management Science, 36 (7), p. 867-883. 